\title{
Influence of Long-Term Communist Confrontation on Inducing Changes in Society and Musical Culture of Hmong Ethnic Group in Thailand
}

\author{
Komphorn Prachumwan $^{1} \&$ Chalermpol Ataso ${ }^{1}$ \\ ${ }^{1}$ Music Education Department, Faculty of Education, Nakhon Phanom University, Thailand \\ Correspondence: Chalermpol Ataso, Music Education Department, Faculty of Education, Nakhon Phanom \\ University, 167/1 Moo 8, Tambon Naratchakwai, Muang District, Nakhon Phanom Province, 48000, Thailand. \\ Tel: 66-88-321-9654. E-mail: chalermpol.ata@gmail.com
}

Received: September 5, 2019

Accepted: October 15, 2019 Online Published: December 18, 2019

doi:10.5539/ach.v12n1p1

URL: https://doi.org/10.5539/ach.v12n1p1

\begin{abstract}
The ethnic group 'Hmong', the descendants of Chinese 'Miao' group who migrated south to reside in Northern Thailand, is known to possess their own unique arts, culture, tradition, and music. However, the influence of social change seemed to largely affect the musical culture of Hmong ethnic, Khao Kho District, Phetchabun Province, in a multifactorial manner. Through different phases of a series of communist wars, the original musical cultures were subjected to the cumulative changes of social contexts, evolving toward modernization, at a great extent. In addition, not only the social changes have had a large impact on the Hmong ethnic's musical cultures, but also on their ritual performances that require music as its core. This study aimed to elucidate the effect of social changes on musical culture by identifying the key contributing factors that determined Hmong's musical performances and appreciation based on their historical features.
\end{abstract}

Keywords: Hmong Ethnic, Communist War, Social Change, Musical Culture, Khao Kho Phetchabun Province

\section{Introduction}

Changes in culture and society tend to emerge regularly in every society and era. The changes differ in terms of the changing patterns and methods that lead to any movement of social evolution. Besides, anthropogenic activities that abuse the existing cultures are the possible cause of the social changes which, eventually, affects local society and cultural practice, such as lifestyles, beliefs, and traditions (Lewin, 1947). In the past, society and culture were subject to the changes at a slow rate because the development of innovations that allow rapid communications and transportations have not yet been established and gradually evolved. The cultural diffusion therefore required a long period of time to become widely recognized. However, the advanced technology in communication have, nowadays, developed and become essential in every part of society, leading to the social civilization and alteration of life's basic requirements (Phillips, 2011). Thus, the rate of social and cultural development has been dramatically accelerated, and the changes in culture and society have also been constantly evolving.

The social and cultural changes, in the past, were caused by several factors such as change of culture in local community, cultural exchanges amongst nearby society, and behavioral adaptation towards the development of modernized society. However, the aforementioned factors only play a minor role in cultural changes of a society, or only slightly affect the cultural popularity deterioration in a society. The factors mediating cultural change that significantly accelerate a change in cultures include population factors, economic factors, political factors, and religious and ideological factors (Inglehart, 1997). The mentioned factors that contribute to cultural changes would potentially cause local culture to change or disappear from a society, and this could drastically affect the social structures and influence the conservation and inheritance of a cultural change in a community (Tilley, 1982).

A number of Hmong ethnic groups are found to reside in Khao Kho District, Phetchabun Province. The orthodox social, cultural and traditional beliefs have been passed on from Hmong ancestors over generations up to now. Hmong ethnic groups in the area of Khao Kho District are relatively divided into several communities i.e. Ban Keg Noi, Ban Keg Yai, Ban Petdum, Ban Kanok Ngam, Ban Fah Moke, Ban Romyen and Ban Lao Lue groups. These groups of Hmong ethnic people have long been following the authentic lifestyles of the ancestral Hmong ethnic people such as performing original agricultural practice and handcrafting their own household items. The lifestyle 
of Mhong Ethnic is chronologically related to the patterns of beliefs, ritual performances, and usage of various Hmong's musical instruments throughout their lifetimes ranging from birth to death. In addition, the Hmong ethnic group have their own unique beliefs and rituals that are inherited from Hmong ancestors through many generations. Based on the previous study, Hmong ethnic group is believed to be the descendants of "Miao" ethnic group that previously resided in China and immigrated to Northern part of Thailand. However, the immigrating time was estimated approximately a hundred years ago, the indication of exact time still remains unclear (Lee, 2007).

Hmong ethnic groups have faced various incidents that led to the social and cultural changes such as civil wars, political influences, religious and ideological factors. In fact, the widely known history of Thailand showed that Khao Kho district once became a battlefield of communistic colonialism (Pawakapan, 2017). Moreover, the current modernization of society and lifestyle is also directly contributed to the changes in Hmong ethnic group society and culture, resulting in the decrease in popularity or, even, disappearing of the original Hmong ethnic groups' lifestyles.

According to the aforementioned concerns, this study aims to elucidate the "Social Change Effects to Musical Culture of Hmong Ethnic at Khao Kho District, Phetchabun Province" in order to build up an incentive to raise the awareness of Hmong ethnic culture conservation and maintain original wisdom of Hmong ethnic for the future generation.

\section{Objectives}

(1) To investigate the effects of social changes on Hmong ethnic community in Khao Kho District, Phetchabun Province.

(2) To study the changes in Hmong's musical culture under the influence of social transition towards civilization in Khao Kho District, Phetchabun Province.

\section{Methodology}

The study, "Social Change Effects to Musical Culture of Hmong Ethnic at Khao Kho District, Phetchabun Province" is a qualitative research. The researcher conducted this study by using document analysis. The information was collected during field study by using preliminary survey form, observation form, and interview form. The structural interview and non-structural interview forms were implemented during the field observation in Ban Keg Noi, Ban Keg Yai, Ban Petdum, Ban Kanok Ngam, Ban Fah Moke, Ban Romyen and Ban Lao Lue in Khao Kho District, Phetchabun Province. The study survey was performed during June 2015-April 2017. The researcher analyzed this study based on the previous published studies, documents from related fields of studies, and data collected from the field observation. The data were divided by focusing on objectives of the research. After that, the information was regularly checked for the accuracy before data analysis and conclusion. Triangulation was used if the data were not consistent and presented in the form of descriptive analysis.

\section{Results}

In this study, the social changes that affect Hmong community in Khao Kho District, Phetchabun Province were found to be multifactorial. For more than a hundred years ago, the Hmong immigrants moved to Thailand through the north border (Lee, 2007). Hmong ethnic group shares a very high similarity to "Miao" ethnic group in China, since Hmong ethnic has brought along the original lifestyles and cultures to Thailand until they became settled and permanently resided in Khao Kho District, Phetchabun Province.

In this study, five periods of Hmong social changes were identified as follows;

\subsection{Pre-War Period (before 1986)}

After relocating to Thailand, the ancestral Hmong immigrants have inhabited in the mountainous areas and plains near Ban Keg Noi, Ban Keg Yai in Khao Kho District, Phetchabun Province. Their life basis primarily relied on agricultural activities, including planting and domesticating livestock. They routinely made crafts for the household purpose. The Hmong ethnic pioneers were community governances and each group had different governances. There are three main groups of the Hmong pioneers;

(1)'มังจั้ว $\quad$ ' H'MOONO NJUA, widely known as Blue Hmong or Black Hmong

(2) ‘ม้งเด๊อว ' H'MOONO DEAW, widely known as White Hmong

(3) 'มังกัวบ๊า ' H'MOONO GUAMBA or Hmong Lai.

Languages and costumes can be used to categorize each Hmong group. In this period, there was the pre-war period "Khao Kho War" approximately in 1965. The war started from communist terrorists invaded and controlled the 
north area and expanded their power throughout "Phu Hin Rong Kla National Park". In 1968, the war started affecting Hmong ethnic group because some Hmong groups had joined the communist colonialism in the fight. Khao Kho War was terminated in 1982, and the war did not largely affect Hmong ethnic group because of the remoted distance between the community area and the battlefield.

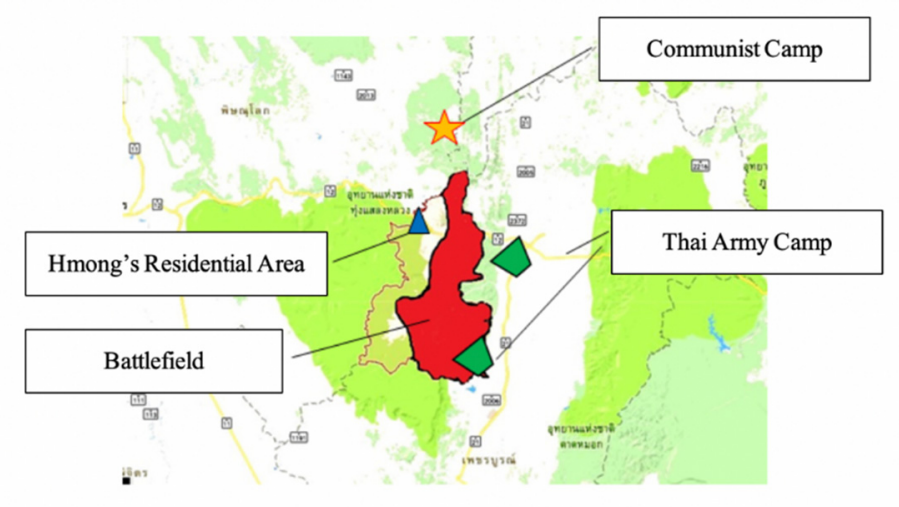

Figure 1. An illustration of locations of the camps of Thai Army and communist party, Hmong ethnic's residential area, and the battlefield

\subsection{Rom Klaow War period (1987-1988)}

The Rom Klaow War started after the end of Khao Kho War. Communist terrorists returned to Phu Hin Rong Kla National Park and formed a haven camp. In the period of Khao Kho War, Khao Kho area was used for the food supply area for the communist forces. Hmong groups in Ban Keg Noi and Ban Keg Yai were forced to work in the food supply area because these people were highly experienced about the location and landscape. The battle, later, had become harsher in December 1987, resulting in the decamping of Ban Keg Noi and Ban Keg Yai population to haven in mountainous areas in Khao Kho District. The distribution allowed the people from Ban Petdum, Ban Kanok Ngam, Ban Fah Moke, Ban Romyen, Ban Lao Lue and other areas to shelter during the raging war before moving back to the previously resided areas. Rom Klaow War was eventually terminated in February 1988. This period has tremendously affected Hmong ethnic group society in the Khao Kho District, Phetchabun Province, until nowadays.

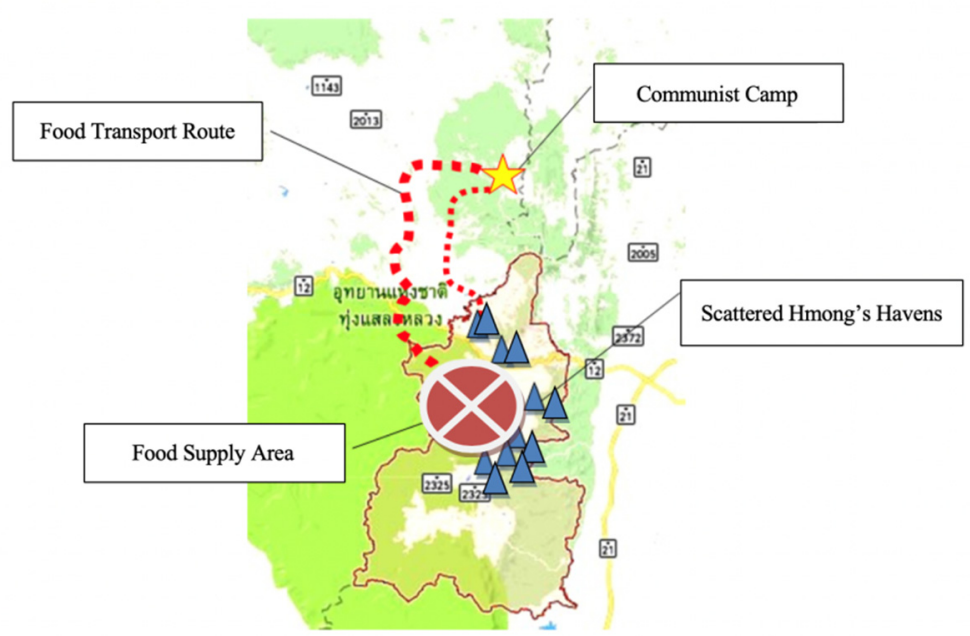

Figure 2. A map indicating of food supply area, food transport route, communist camp, and distribution of Hmong ethnic's haven sites 


\subsection{Recovery Period (1989-2001)}

This period was also known as a post-war period at which Hmong ethnic group residence and society were recovered after the end of war. Hmong ethnic people who had distributed to mountain areas recovered their political factors and established more systematic governance by obtaining the guidelines and supports from Thai government. There were usages of basic consumption, setting up of government offices, such as police stations, local hospitals, city halls, medical units, tap water supply offices, electricity system and implementing the King's sustainable projects to help Hmong people improve their life qualities. Hmong ethnic groups' societies has changed significantly during this recovery period. The local government imposed more effective regulations in Khao Kho District and became more powerful which has resulted in the change from internal ethnic group governance into local government.

\subsection{Cultural Changes and Development Period (2002-2016)}

In this period, the residential areas of Hmong ethnic group became more interesting in terms of the beautiful landscapes and natural environment. The areas have been turned from a battlefield into a popular tourism area, attracting loads of tourists from Thailand or, even, around the world. The tourism industry and economy of Khao Kho district then rapidly grew. Therefore, the unavoidable influences from the active tourism business and growing economic prosperity, including construction of accommodations, i.e. hotels and resorts, and introduction of public or private transportation, would eventually affect the roots of original society and culture of the ancestral Hmong ethnic group. Various factors, including agricultural activity, animal domestication, folk belief, tradition, music and lifestyle were significantly disregarded and became less important over time. Self-adaptation to meet life basic needs became more vital in order to synchronize with the modernized world. Globalization and technological development have directly affected Hmong ethnic group's society and culture and the local Hmong culture has become more overlooked.

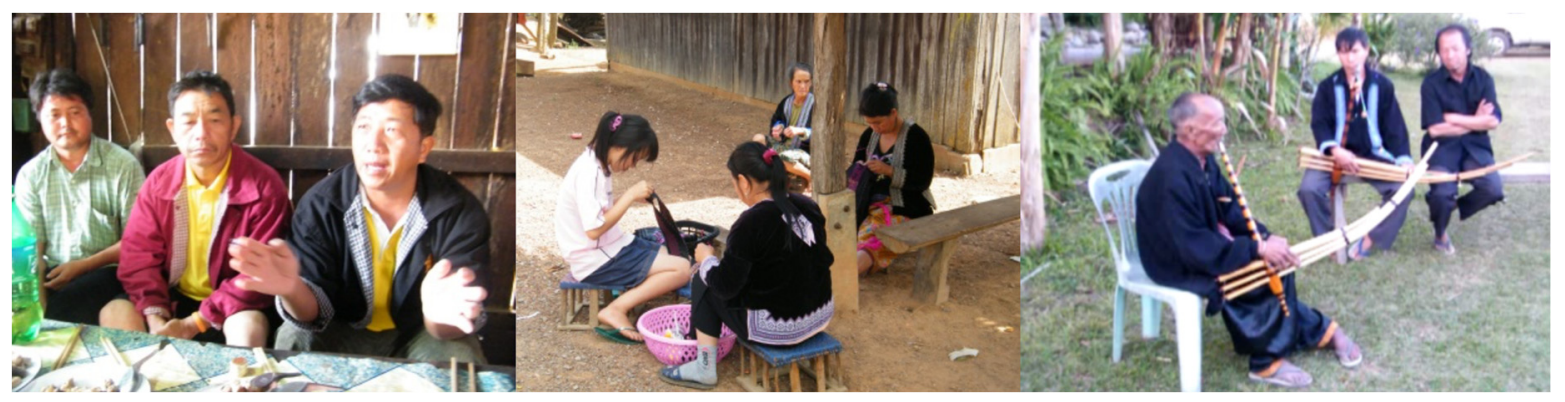

Figure 3. Interview with local Hmong ethnic people and observation of their traditional activities. Left: Casual interview with the local people. Middle: Traditional textile weaving by women of different ages. Right: Casual musical performance using traditional musical instruments

\subsection{Present Period (2017)}

Nowadays, the distinctive changes in art, culture, and tradition have been continuously growing. These changes were believed to be contributed by several factors which are thoroughly explained in this section. For the demographic factor, Khao Kho District, Phetchabun Province had long been recognized as a 'red zone' for more than 40 years because of the relentless communist war that terrified people into abandoning their homeland or discouraged the new civilians to move in, leading to a constant drop of population size. However, nowadays, Khao Kho District, Phetchabun Province has been popular for the tourism industry, so the area is now fully filled with good facilities and infrastructure. Therefore, the number of people desiring to inhabit in Khao Kho area has been increasing and the land and property marketing has become increasingly popular. This factor certainly contributes to social and cultural changes in Khao Kho area, so Hmong's culture has finally become a combination of the cultures derived from the newly resident people and the local people.

For the economic factor, due to the increased popularity of tourism, many investors were attracted to launch their business in Khao Kho District. Apart from tourism-related business, agricultural business has drawn attentions from a huge number of entrepreneurs. In Thailand, there are many plain areas which are suitable for plantation and agriculture. According to the cold average temperature in Khao Kho area, the cold-climate species of plants are 
able to survive in this area. It is widely known that the development of economic factors always affects the original society and culture either directly or indirectly. Therefore, the change in society and culture of Hmong ethnic group is inevitable.

For the religious and ideological factors, in the past, Hmong ethnic group living in Khao Kho District, Phetchabun Province believed in superstitions and predecessors. Later, Christianity became more popular in the area and, then, followed by the predominance of Buddhism. As a result, there have been the diversity of beliefs in Khao Kho community. The appearance of architecture that symbolizes different religions is situated in Khao Kho area such as spirit houses, Christian churches, and Buddhism temples. Changes in religion and ideology directly influence people's belief at a great extent, so the social and cultural changes would concomitantly occur in a community.

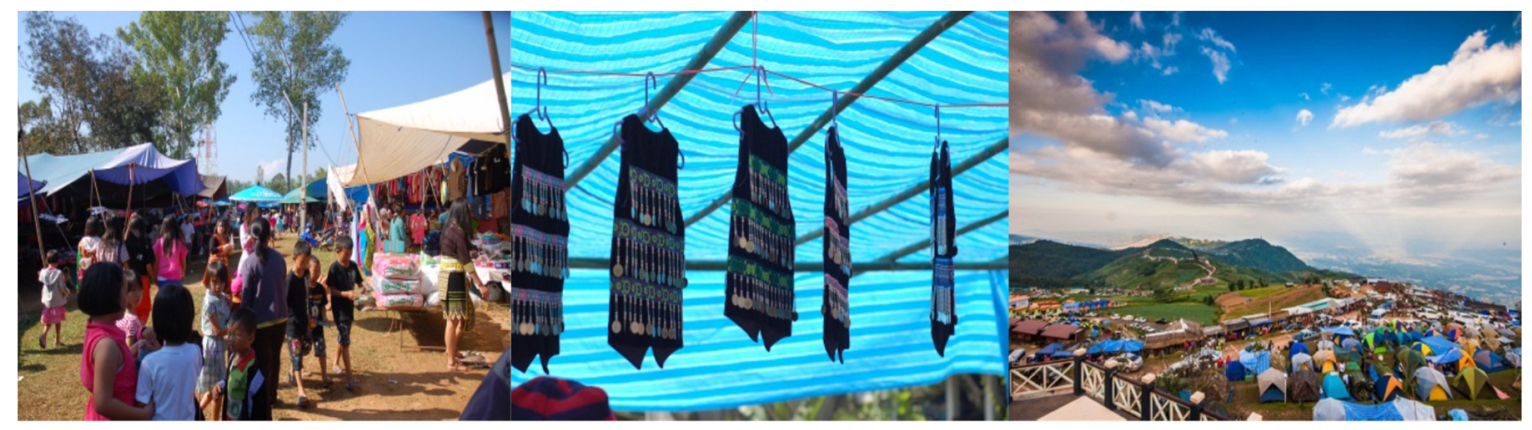

Figure 4. The rapid growth of tourism industry in Khao Kho District, Petchabun Province

Musical cultures of Hmong ethnic group which were changed following social changes in Ban Keg Noi, Ban Keg Yai, Ban Petdum, Ban Kanok Ngam, Ban Fah Moke, Ban Romyen and Ban Lao Lue in Khao Kho District, Phetchabun Province consist of three changes as follows;

\subsection{Original Culture Period (before 1986-1474)}

This age was full of original beliefs and traditions inherited from ancestral Hmong ethnic group in Khao Kho District, Phetchabun Province. In this period, the people strongly believed and followed the cultures that are consistent with their lifestyles. Hmong ethnic group had lived in the mountain area for a long time. The belief and tradition consisted of ghost, spirit, mountain spirit, and house spirit. Hmong ethnic group in original culture period strictly believed and followed the original cultures, so they got a lot of diversity traditions. The cultures and tradition matched with the social changes in pre-war period (before 1986), Rom Klaow War period (1987-1988) and Recovery period (1989-2001). Although, there were the wars in the area for a long time, the Hmong ethnic group still put their full effort to maintain their original beliefs, cultures, traditions, rites, and music.

In terms of tradition and culture, Hmong ethnic group's musical culture had been changed due to the slight changes in society in the original culture period (before 1986-1474). 23 rites were found to be performed by Hmong ethnic group in Khao Kho District, Phetchabun Province, which were New Year rite, fresh rice eating rite, wedding, naming rite, Tongseng rite, drum worship rite, Suatroa rite, Phee Yeng rite, Pao Yeng rite, Auneng Kua Dah rite, Yasae Meng rite, Au Juda rite, Auneng rite, Tor Seng rite, Sua Kuchua rite, Nier Kua Chee Kua rite, Buatai rite, Datrong rite, Too Soo rite, name changing rite, funeral, purchasing rite, and Jor Plee rite (Mongkholchai, 2005).

The musical instruments of Hmong ethnic group in Khao Kho District, Phetchabun Province were modified due to the effect of social changes in original culture period (before 1986-1474) and they were divided into three types as follows;

- Aerophone Instruments; Neas, Tsaaj Pum Liv, Qeej and Nplooj

- Siring Instrument; Tsaaj Tsiav

- Percussion Instruments; Nruag, Nrusg Neeb, and Tswb Neeb

In this period, Hmong ethnic group only made their life accessible to essential basic life requirements; shelter, costume, food, and nutrition. Therefore, the lifestyle and culture of Hmong people at this time was found to be very unique and primitive. 


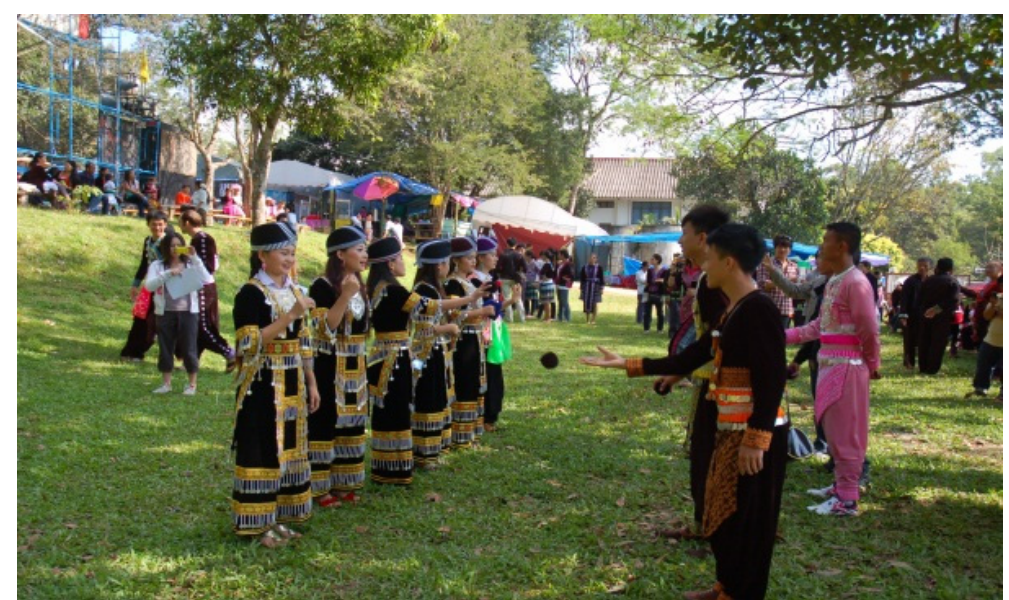

Figure 5. 'Yone Look Chuang' ceremony performed by male and female teenagers

\subsection{Cultural Change Period (2002-2012)}

During this period, the social and cultural changes largely affected the culture, tradition, lifestyles and musical culture of Hmong ethnic group living in Khao Kho District, Phetchabun Province. The factors that affected to social and cultural changes included war period, politics, populations, economy, religion and ideology factor. These factors have effects to the society. In addition, there are the direct effectiveness to the changing of culture of Hmong ethnic group. The changes to make it able to fit with social and political system, changing from internal group governance to government, population increased, immigrations to settle or run business, agricultural industry, economic changes, globalization, transportation, communication, education, tourism, consummation and city cultural and social changes. Moreover, for the religion and ideology changes, original Hmong ethnic group previously believed in and worshipped invisible ghosts and spirits, while the dominance of Christianity and Buddhism, later, has overcome the original belief which dramatically affect to the indigenous community, social structure, and culture (Ataso et al., 2019).

Based on the change in tradition and rites following social changes in recovery period (1989-2001) and cultural changes and development period (2002-2016), 18 rites were found to be performed by Hmong ethnic group in Khao Kho District, Phetchabun Province, which were New Year rite, fresh rice eating rite, wedding, naming rite, Tongseng rite, drum worship rite, Suatroa rite, Phee Yeng rite, Pao Yeng rite, Yasae Meng rite, Au Juda rite, Buatai rite, Datrong rite, Too Soo rite, name changing rite, funeral, purchasing rite, and Jor Plee rite (Soonthorn, 2011).

Musical instruments of Hmong ethnic group in Khao Kho District, Phetchabun Province were found to be subjected to social changes in the recovery period (1989-2001) and cultural changes and development period (2002-2016). The musical instruments used during this era are shown as follows;

- Aerophone Instruments; Neas, Tsaaj Pum Liv, Qeej and Nplooj

- Siring Instrument; Tsaaj Tsiav

- Percussion Instruments; Nruag, Nrusg Neeb, and Tswb Neeb

In addition, in this period, Hmong ethnic group not only plays Qeej in religious rites but also for their entertaining recreational activities.

\subsection{Present Period (2013-2017)}

This period was when social and cultural changes could be clearly seen through the conversion of original career paths from agricultural activities into accommodating services, such as hotels and resorts, to support tourism industry. In the past, for example, Hmong dress weavings were only used in households, but nowadays, it has been used for sale in markets for the sake of tourism business. Agricultural activities have become more intense because of the growing business and investment in foreign species plantation, instead of cultivating domestic plants. This also affects the soil fertility and natural sustainability due to the forest invasion to boost the volume of agricultural productivity. Therefore, the original Hmong ethnic group's lifestyles were replaced and influenced by modernized education, economy, politics, and technology. Furthermore, the belief in ghost and spirit were also replaced by Christianity and Buddhism. Although, most of original cultural practices have not been found to happen in real life, 
they are being conserved for education and passed on from generation to generation via education in school and library.

The traditions and rites have become extremely different from the ancestral pattern, since there are development and advancement in various aspects that directly affect the social structure and community in the present period (2017). 10 rites were found to remain performed by the new generation of Hmong ethnic group in Khao Kho District, Phetchabun Province, including New Year rite, fresh rice eating rite, wedding, naming rite, Tongseng rite, Au Juda rite, Too Soo rite, funeral, purchasing rite, and Jor Plee rite.

Several musical instruments of Hmong ethnic group in Khao Kho District, Phetchabun Province in the present period (2017) were found to disappear from the past due to the social changes towards the global modernization. The musical instruments were divided into two types as follows;

- Aerophone Instruments; Qeej and Nplooj

- Percussion Instruments; Nruag and Tswb Neeb

According to the aforementioned ten rites found in the present period (2013-2017), in the community, we found that the rites that have been continuously performed in the area of Khao Kho District, Phetchabun Province up to now were New Year rite, wedding (only found in original Hmong ethnic groups who believe in ghosts and spirits), and funeral. We also found that Qeej is the most important musical instrument for Hmong ethnic group, because Qeej is believed to be a mediator that allows communication with the spirits (Aimaot, 2000), so it is played during the ritual performance. Since there is the belief about life after death, Qeej, in funeral, becomes the key musical instrument of the ceremony. Therefore, Qeej is played intermittently at three different time points; morning, lunch and evening times and it cannot be played in a band with other instruments. Women were not allowed to play Qeej in funeral.

In this study, a variety of traditions, cultures, rites and musical instruments were found to be unique to the Hmong community. Ethnic group's musical performance requires understanding, knowledge and skills acquired from a long-term experience. The effect of social and cultural change might discourage the new generation of Hmong ethnic people to learn the Hmong's classical music that would possibly result in a disappearance of this valuable culture.

\section{Discussion and Conclusion}

The effects of social change on the musical culture of Hmong ethnic in Khao Kho District, Phetchabun Province were investigated based on the historical timeline. In the pre-war period (before 1986), the initial Hmong immigrants moved to Thailand and inhabited in mountains and plains near Ban Keg Noi, Ban Keg Yai in Khao Kho District, Phetchabun Province. They were, then, split into three main groups as reported by the previous study (Buraphat, 1985). Languages and costume were used to categorize each Hmong group. In this period, it was the initial period of "Khao Kho War" started in 1965 by communist terrorists and the war was terminated in 1982. There were not many serious effects on Hmong ethnic group because of the remote distance between locations of the residential and war areas. Until 1986, Rom Klow war period was the war period in Khao Kho District, Phetchabun Province that directly affected Hmong ethnic group's society and culture. During post-war period, reestablishment of Hmong ethnic group residences was proceeded after the war had been terminated. Governance re-organization led the Hmong people to regain their political power with the support from Thai government. This has provoked a major transformation of Hmong ethnic's culture and society towards modernization resulted from a rapid growth of tourism industry and introduction of advanced technology to the area. Cumulative changes in culture and society have been, nowadays, obviously shown via modernized art, culture, and tradition (Adiwattanasit, 1998). Social and cultural changes are triggered by four factors which are the change in people's mindset, behavioral changes, dynamic changes in personal and group relationship, and changes in cultural structure in a community or society (Keawnuch, 2010). Moreover, the Hmong's cultural changes are evidently subjected to the transformation of belief and social change which ultimately resulted in the changes in musical culture. Hmong ethnic group's musical culture change influenced by social changes in Khao Kho District, Phetchabun Province is chronologically divided into three periods of changes based on the discovery of dynamic changes in ritual performance, pattern and musical instruments used for ceremonies, and transition of religious believes. Qeej, for example, was also identified as a major musical instrument used in both spiritual and religious ceremonies, since Qeej is believed to allow Hmong ethnic people to communicate with the invisibles.

The factors that have been constantly affecting and shaping Hmong ethnic group's society and culture in Phetchabun Province from the past to the present are comprised of a variety of factors e.g. communist war 
periods, politics, population dynamics, economics, religions and ideological factors. These factors have become the reasons for the changes in lifestyle, belief, traditions, rites, and musical cultures which are constantly passed on over countless generations of Hmong ethnic group. Up to now, the unique Hmong's original lifestyle and cultures have become less popular and rapidly been replaced by the modernization. It is important to encourage and raise the awareness for the new generation to conserve their uniqueness of the Hmong ethnic, such as belief, culture, and tradition to enable sustainable conservation and the succession of wisdom.

\section{Acknowledgement}

This research was kindly funded by research grant from Center for Educational Research and Innovation, Faculty of Education, Nakhon Phanom University. The authors would like to thank Kasidit Rattanawong for his diligent proofreading of this paper.

\section{Conflict of interests}

The authors declare that there is no conflict of interests regarding the publication of this paper.

\section{References}

Adiwattanasit, J. (1998). Ethics Development. Kasetsart Educational Review.

Aimaot, W. (2000). Qeej: Hmong ethnic group music instrument (Dissertation). Mahidol University, Bangkok, Thailand.

Ataso, C., \& Champasakdi, P. N. (2019). Influence of Spiritualistic Belief on Musical Performance in Traditional Ritual: Mahesak City Guardian Ceremony in Champasak. Asian Culture and History, 11(1), 23.

Buruphat, K. (1985). Minorities in Thailand. Bangkok: Phaer Pittaya.

Inglehart, R. (1997). Modernization and postmodernization: Cultural, economic, and political change in 43 societies. Princeton university press.

Keawnuch, K. (2010). The Perceptions of Members of the Karen And Hmong Hill Tribes of the Impacts Upon Their Communities Resulting from the Development of Tourism in Northern Thailand (Doctoral dissertation). Bournemouth University. Bournemouth. United Kingdom.

Lee, G. (2007). Diaspora and the predicament of origins: Interrogating Hmong postcolonial history and identity. Hmong Studies Journal, 8.

Lewin, K. (1947). Frontiers in group dynamics: Concept, method and reality in social science; social equilibria and social change. Human Relations, 1(1), 5-41.

Mongkholchai, S. (2005). Hmong Ethnic Group New Year, Ban Toop Kor, Boksatorn Sub District, Dansai, Loei Province (Master dissertation). Rajabhat Loei University. Loei. Thailand.

Pawakapan, P. R. (2017). The central role of Thailand's internal security operations command in the post-counter-insurgency period. Trends in Southeast Asia, 17, 0219-3213.

Phillips, F. (2011). The state of technological and social change: Impressions. Technological Forecasting and Social Change, 78(6), 1072-1078.

Soonthorn, T. (2011). Qeej Apophysiology and Playing of Hmong ethnic group in Keknoi Sub District, Khao Kho District, Phetchabun Province (Dissertation). Mahasarakham University. Mahasarakham Province, Thailand.

Tilley, C. (1982). Social formation, social structures and social change. Symbolic and Structural Archaeology, 26-38.

\section{Copyrights}

Copyright for this article is retained by the author(s), with first publication rights granted to the journal.

This is an open-access article distributed under the terms and conditions of the Creative Commons Attribution license (http://creativecommons.org/licenses/by/4.0/). 